\title{
Comparison of demographic and procedural characteristics of patients with elective percutaneous coronary interventions according to the presence of in-stent restenosis: biannual results from the University Hospital Merkur
}

\section{Tomislav Letilović*, \\ Damir Kozmar, \\ Stjepan Kranjčević, Darko Počanić, \\ Helena Jerkić, Maro Dragičević, Mario Stipinović, Ena Kurtić}

University Hospital Merkur, Zagreb, Croatia
RECEIVED:

February 6, 2016

ACCEPTED:

February 20, 2016

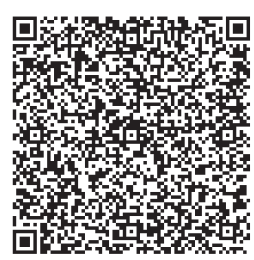

KEYWORDS: in-stent restenosis, percutaneous coronary intervention, drug-eluting stent, drug-elutin ballon.

CITATION: Cardiol Croat. 2016;11(3-4):121-122. | DOI: http://dx.doi.org/10.15836/ccar2016.121

*ADDRESS FOR CORRESPONDENCE: Tomislav Letilović, Klinička bolnica Merkur, Zajčeva 19, HR-10000 Zagreb, Croatia. / Phone: +385-98-782-002 / E-mail: letilovic@yahoo.com

ORCID: Tomislav Letilović, http://orcid.org/0000-0003-1229-7983 • Damir Kozmar, http://orcid.org/0000-0001-7626-3534 Stjepan Kranjčević, http://orcid.org/0000-0002-1575-1902 • Darko Počanić, http://orcid.org/0000-0003-3257-110x Helena Jerkić, http://orcid.org/0000-0002-1650-4735 • Maro Dragičević, http://orcid.org/0000-0002-2620-3194 Mario Stipinović, http://orcid.org/0000-0002-1582-1552 • Ena Kurtić, http://orcid.org/0000-0001-6673-6510

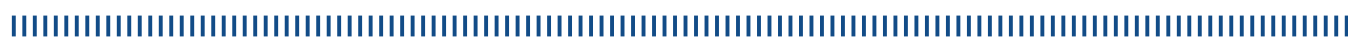

Background: In-stent restenosis (ISR) is an important clinical problem. Underlying cause of ISR can be variable and is believed to be different from the pathophysiology of atherosclerosis in the native vessels. ${ }^{1}$ Such different mechanisms could, at least in part, be explained by different demographic characteristics of ISR and non-ISR patients. They could also lead to different approaches to percutaneous coronary interventions (PCI) in those two groups.

Patients and Methods: We conducted this retrospective analysis, of our interventional data, in order to find such differences. In years 2014 and 2015 there were 657 elective PCI procedures (41 ISR and 616 non ISR interventions) in our institution.

Results: We found no significant differences in major demographic characteristics in ISR vs. non-ISR patients (Table 1). Analysis of procedural characteristics (Table 2) showed that we were probably more aggressive with predilatation in ISR (number of balloons used $1.53 \pm 0.59$ vs. $1.34 \pm 0.77 ; p=0.03$ ). We were less keen to implant a stent in ISR patients (21.9\% vs. $82.3 \%$; $\mathrm{p}<0.001)$ but when implanted one it was more frequently a drug eluting stent ( $100 \%$ vs. $36.9 \%$; $<0.001)$. We used more drug eluting balloons for ISR (65.8\% vs. $3.7 \% ; \mathrm{p}<0.001)$. No other significant differences in procedural characteristics examined were found.

TABLE 1. Demographic characteristics of patients according to the presence of in-stent restenosis.

\begin{tabular}{lrrr} 
Characteristic & ISR $(\mathbf{n}=41)$ & Non ISR $(\mathbf{n}=616)$ & p-value \\
\hline Age (mean士SD) & $65.9 \pm 7.9$ & $64.3 \pm 9.7$ & 0.38 \\
\hline Male sex (n/\%) & $31 / 77.5$ & $434 / 70.4$ & 0.48 \\
\hline Hypertension (n/\%) & $40 / 97.5$ & $587 / 95.3$ & 0.52 \\
\hline Hyperlipidaemia (n/\%) & $41 / 100$ & $566 / 91.8$ & 0.06 \\
\hline Smoking (n/\%) & $9 / 21.9$ & $177 / 28.7$ & 0.56 \\
\hline Diabetes (n/\%) & $11 / 26.8$ & $208 / 33.7$ & 0.92 \\
\hline Previous MI (n/\%) & $22 / 53.6$ & $284 / 46.1$ & 0.89 \\
\hline Previous PCI (n/\%) & $41 / 100$ & $193 / 31.3$ & $<0.001 *$ \\
\hline Previous CABG (n/\%) & $1 / 2.4$ & $19 / 3.0$ & 0.25
\end{tabular}

$\mathrm{ISR}=$ in-stent restenosis; $\mathrm{MI}=$ myocardial infarction; $\mathrm{PCI}=$ percutaneous coronary intervention; $\mathrm{CABG}=$ coronary artery bypass graft; $\mathrm{n}=$ number; $\mathrm{SD}=$ standard deviation. Mann Whitney test was used for continuous and chisquare for nominal variables. * $<0.05$ 
Conclusion: There were no significant demographic differences in ISR vs. non-ISR patients treated in our institution. Procedural differences that were found reflect, at least in some part, well known recommendations for ISR interventions. On the other hand, they also probably reflect specific organizational and financial issues of our catheterization laboratory.

\section{TABLE 2. Procedural characetristic.}

\begin{tabular}{|c|c|c|c|}
\hline Characteristic & ISR $(n=41)$ & Non ISR $(n=616)$ & p-value \\
\hline LAD//Cx//RCA//Graft//LMCA (n) & $15 / / 5 / / 19 / / 1 / / 1$ & $187 / 161 / 258 / 1 / 9$ & 0.47 \\
\hline Predilatation (n/\%) & $41 / 100$ & $557 / 90.4$ & 0.14 \\
\hline Number of balloons - predilatation (mean $\pm S D$ ) & $1.53 \pm 0.59$ & $1.34 \pm 0.77$ & $0.03 *$ \\
\hline Stent implantation (n/\%) & $9 / 21.9$ & $507 / 82.3$ & $<0.001 *$ \\
\hline Number of implanted stents (mean \pm SD) & $1.0 \pm 0.31$ & $1.12 \pm 0.51$ & 0.31 \\
\hline DES penetration $(n / \%)$ & $9 / 100$ & $219 / 36.9$ & $<0,001 *$ \\
\hline DEB application ( $\mathrm{n} / \%)$ & $27 / 65.8$ & $23 / 3.7$ & $<0.001 *$ \\
\hline Postdilatation (n/\%) & $1 / 2.4$ & $62 / 10.0$ & 0.10 \\
\hline Fluoro time in min (mean $\pm S D)$ & $8.04 \pm 4.51$ & $10.09 \pm 9.24$ & 0.69 \\
\hline Contrast in $\mathrm{ml}$ (mean \pm SD) & $159.41 \pm 67.26$ & $165.15 \pm 77.49$ & 0.76 \\
\hline
\end{tabular}

ISR = in-stent restenosis; $L A D=$ left anterior descending; $C x=$ circumflex; $R C A=$ right coronary artery; $L M C A=$ left-main coronary artery; $D E S$ = drug-eluting stent; $\mathrm{DEB}=$ drug-eluting balloon; $\mathrm{n}=$ number; $\mathrm{SD}=$ standard deviation. Mann Whitney test was used for continuous and chi-square for nominal variables. * $\mathrm{p}<0.05$ 